Supplemental Information for:

\title{
Controlled Recovery of the Transcription of Nanoparticle-Bound DNA by Intracellular Concentrations of Glutathione
}

\author{
Gang Han, Nandini S. Chari ${ }^{\S}$ Ayush Verma, Rui Hong, \\ Craig T. Martin, Vincent M. Rotello*
}

\section{Synthesis of MMPCs and Peptide 3.}

MMPC $\mathbf{1}$ and $\mathbf{2}$ and peptide $\mathbf{3}$ were synthesized as previously reported $(1,2,3)$.

\section{DNA oligonucleotides synthesis and purifucation.}

Oligonucleotides were synthesized (1.0 $\square \mathrm{mol}$ scale) on a Perseptive Biosystems Expedite 8909 Nucleic Acids Synthesis System using standard procedures. Cleavage from the support and base deprotection was accomplished by treatment with concentrated $\mathrm{NH}_{4} \mathrm{OH}$ $\left(16 \mathrm{~h}, 37^{\circ} \mathrm{C}\right)$. Strands were purified via denaturing polyacrylamide gel electrophoresis, excised from the gel, and eluted using an Elu-Trap ${ }^{\circledR}$ device (Schleicher and Schuell Inc.) The 37 mer DNA sequence encoding a 20mer RNA is:

\section{5' - TAATACGACTCACTATAGGGAGACCACAACGGTTTCC -3' \\ 3'- ATTATGCTGAGTGATATCCC TCTGGTGTTGCCAAAGG- 5'}

The oligomers were then concentrated to dryness and redissolved in TE buffer $(10 \mathrm{mM}$ Tris, pH 7.8, and 1mM EDTA). Concentrations of single-stranded DNA were calculated using the weight sums of the different measured molar extinction coefficients for each base at 253, 259, and $267 \mathrm{~nm}$. Complementary strands were annealed by combining equivalent molar amounts of the individual sequences (100 $\square \mathrm{M}$ final concentration), heating to $90^{\circ} \mathrm{C}$ for $5 \mathrm{~min}$, and slowly cooling to room temperature. DNA was stored at $-20^{\circ} \mathrm{C}$.

\section{Ethidium bromide assay}

This assay was modified from a reported procedure (4). Samples were prepared in phosphate buffer saline ( $\mathrm{pH}=7.8,20 \mathrm{mM}$ potassium phosphate, $100 \mathrm{mM}$ sodium chloride) 
except as noted. The DNA 37mer was diluted from a stock solution of $100 \square \mathrm{M}$ to 0.25 $\square$ M. Ethidium bromide was diluted from a stock solution of $1 \mathrm{mM}$ to $5 \square \mathrm{M}$. MMPC 1 and MMPC 2 were added in aliquots to the DNA solution from a $100 \square \mathrm{M}$ stock in $\mathrm{ddH}_{2} \mathrm{O}$. $0.25 \square \mathrm{M}$ of DNA was incubated with $1 \square \mathrm{M}$ of MMPCs for about 5 minutes after which reduced glutathione $(\mathrm{GSH})$ and peptide 3 was added from a 100mM freshly prepared stock solution ( $\mathrm{pH}$ was adjusted to 7.8) Final concentrations of GSH were $0 \mu \mathrm{M}, 2 \mu \mathrm{M}, 10 \mu \mathrm{M}, 500 \mu \mathrm{M}, 1 \mathrm{mM}, 5 \mathrm{mM}$ and $10 \mathrm{mM}$ and peptide 3 was $10 \mathrm{mM}$. After 1 hour incubation at $37^{\circ} \mathrm{C}$, spectra were obtained on a Shimadzu RF-5301 PC spectrofluorophotometer, using a quartz cuvette with dimensions 2 X $10 \mathrm{~mm}$ (lamp excited along long axis). $\square_{\mathrm{em}}=595 \mathrm{~nm}\left(\square_{\mathrm{ex}}=545 \mathrm{~nm}\right)$. The excitation slit width was set at 1.5 or $3 \mathrm{~nm}$, and the emission slit width set at 10 or $20 \mathrm{~nm}$. For each spectrum, scans were collected at a 'very fast' speed, using auto response and high sensitivity. The fluorescence intensities relative to controls at selected wavelength $(595 \mathrm{~nm})$ were plotted.

\section{T7 RNA Polymerase Assay}

This assay was modified according to previously described (5). The assay was done using PBS buffer ( $\mathrm{pH}=7.8,20 \mathrm{mM}$ potassium phosphate, $100 \mathrm{mM}$ sodium chloride) except as noted. To mediate reversal of inhibition of DNA transcription, premixed (5min) DNAMMPC (4 equivalents of MMPC per DNA strand) solutions were incubated with different concentrations of GSH $(0 \mu \mathrm{M}, 2 \mu \mathrm{M}, 10 \mu \mathrm{M}, 500 \mu \mathrm{M}, 1 \mathrm{mM}, 5 \mathrm{mM}, 10 \mathrm{mM})$ and $10 \mathrm{mM}$ peptide 3 for 1 hour at $37^{\circ} \mathrm{C}$. The incubation was followed by addition of the $\mathrm{T} 7$

RNA polymerase and the excess nucleotide tri-phosphates including ${ }^{32} \mathrm{P}$-labeled GTP for isotopic detection to a final 1:1 enzyme: DNA ratio $(0.2 \square \mathrm{M})$. The enzymatic reaction proceeds for $5 \mathrm{~min}$ before being quenched with $15 \mathrm{mmol}$ of EDTA in $95 \%$ formamide. The 20 mer RNA transcripts were resolved by $20 \%$ polyacrylamide and $7 \mathrm{M}$ urea gel electrophoresis and visualized and quantified using a Storm 840 phosphorimager (Amersham Bioscience) to determine the extent of reactions, with the transcription levels attained in the absence of MMPCs at corresponding GSH and peptide $\mathbf{3}$ concentrations set to $100 \%$ transcription. 


\section{Zeta potential assay:}

Zeta potentials were measured by a MALVERN Zetasizer Nano ZS after MMPC 1 and 2 $(0.8 \mu \mathrm{M})$ were incubated without and with $10 \mathrm{mM}$ of GSH and peptide 3 separately for 1 $\mathrm{h}$ at $37^{\circ} \mathrm{C}$ in $\mathrm{PBS}$ buffer $(\mathrm{pH}=7.8,20 \mathrm{mM}$ potassium phosphate, $100 \mathrm{mM}$ sodium chloride). Three rounds of assays have been operated. The average data were plotted.

\section{References}

1. Verma, A., Simard, J. M., Worrall, J. W. E., and Rotello, V. M. (2004) Tunable reactivation of nanoparticle-inhibited beta-galactosidase by glutathione at intracellular concentrations. J. Am. Chem. Soc. 126, 13987-13991.

2 .McIntosh, C. M., Esposito, E. A., Boal, A. K., Simard, J. M., Martin, C. T., and Rotello, V. M. (2001) Inhibition of DNA transcription using cationic mixed monolayer protected gold clusters. J. Am. Chem. Soc. 123, 7626-7629.

3. Kwon, D. S., Lin, C. H., Chen, S. J., Coward, J. K., Walsh, C. T., and Bollinger, J. M. (1997) Dissection of glutathionylspermidine synthetase/amidase from Escherichia coli into autonomously folding and functional synthetase and amidase domains. J. Biol. Chem. 272, 2429-2436.

4. Boger, D. L., Fink, B. E., Brunette, S. R., Tse, W. C., and Hedrick, M. P. (2001) A simple, high-resolution method for establishing DNA binding affinity and sequence selectivity. J. Am. Chem. Soc. 123, 5878-5891.

5. Gong, P., Esposito, E. A., and Martin, C. T. (2004) Initial bubble collapse plays a key role in the transition to elongation in T7 RNA polymerase. J. Biol. Chem. 279, 4427744285. 